\title{
Recombinant activated factor VII in cardiac surgery - first, do no
}

\author{
harm \\ Oliver J Warren*, Ara W Darzi and Thanos Athanasiou
}

\begin{abstract}
Address: Department of BioSurgery and Surgical Technology, Imperial College London, 10th Floor QEQM Wing, St. Mary's Hospital, Praed Street, London, W2 $1 \mathrm{NY}$, UK

Email: Oliver J Warren* - o.warren@imperial.ac.uk; Ara W Darzi - a.darzi@imperial.ac.uk; Thanos Athanasiou - tathan5253@aol.com

* Corresponding author
\end{abstract}

Published: 24 November 2007

Journal of Cardiothoracic Surgery 2007, 2:50 doi:10.1 186/1749-8090-2-50

Received: 30 October 2007

Accepted: 24 November 2007

This article is available from: http://www.cardiothoracicsurgery.org/content/2/I/50

(c) 2007 Warren et al; licensee BioMed Central Ltd.

This is an Open Access article distributed under the terms of the Creative Commons Attribution License (http://creativecommons.org/licenses/by/2.0), which permits unrestricted use, distribution, and reproduction in any medium, provided the original work is properly cited.

\section{Letter to the editor}

We read with interest Heise et al's case report and review of the literature regarding the use of recombinant activated factor VII (rFVIIa) in patients with ventricular assist devices (VAD) [1]. Whilst we welcome the addition to the literature in this area, there are two key areas regarding this relatively novel haemostatic agent that we felt the authors had failed to address appropriately, and that may therefore mislead the practicing cardiac surgeon.

RFVIla's method of action; the source and role of tissue factor in cardiac surgery patients

In their discussion, the authors state that 'the effect of rFVIIa on plasmatic coagulation derives from its interaction with tissue factor. Thus, the pro-coagulatory effect is predominantly located in regions where tissues or vessels are injured'. This is a simplification of a highly complex and only partially understood process. The authors have based their statement on what we know of endogenous Factor VIIa and Tissue Factor (TF) interaction in physiological conditions, where TF is present as an inactive pool on subendothelial cells. Vessel injury exposes this TF to the blood, where it binds and activates FVII. The resulting TFFVIIa complex catalyzes the conversion of factor $\mathrm{X}$ into its active form (Xa), leading to thrombin formation and platelet activation. This creates a surface that supports the binding of coagulation factors and thereby facilitates the full thrombin burst necessary for haemostasis.

One cannot presume that the pro-coagulatory effect of rFVIIa occurs in the same way in patients undergoing VAD surgery; significant controversy exists surrounding both the source and the role of tissue factor in this setting. The systemic inflammatory response witnessed in patients undergoing major cardiac surgery involving artificial circulatory support has a profound impact on the coagulation system and thus TF expression is highly unlikely to be restricted to the sub-endothelium. Several groups of investigators have reported the presence of physiologically active 'blood-borne TF' in pro-inflammatory conditions, including cardiac surgery [2-4]. What form this takes remains unclear; blood-borne TF has been reported as being located on blood cells, being an undefined mixture of pro-coagulant micro-particles $(0.1$ to $1 \mu \mathrm{m})$ or being soluble pro-coagulant TF fragments [5-7]. Pro-inflammatory cytokines can stimulate neutrophils and monocytes to produce and present TF on their surface $[8,9]$ and blood-borne TF in combination with activated monocytes may activate FVII in cardiac surgical patients more than when combined with activated platelets $[2,10]$. Furthermore, many patients undergoing VAD surgery suffer from ischaemic cardiomyopathy. Within atherosclerotic plaques, vascular smooth muscle cells, monocytes and endothelial cells have all been reported to aberrantly express and expose TF to the circulation [11]. Not only has this been shown to be a critical event in atherothrombosis, but this expression and exposition has been shown to occur at higher levels in patients with symptomatic coronary disease, suggesting a role for TF in plaque instability [12].

The exact role of TF in rFVIIa's effect also requires further elucidation. The high plasma concentrations of rFVIIa required to induce haemostasis in refractory haemorrhage 
suggests that TF-dependent activation of the coagulation cascade cannot be the sole mechanism of action. It has been shown that rFVIIa is able to directly activate Factor X on phospholipid vesicles, activated platelets and monocytes, independently of TF [13-15], although TF-independent generation of thrombin is much less efficient. Whilst the authors alluded to TF-independent thrombin generation in their introduction we feel this point must be emphasised.

\section{Patient safety - the risk of thromboembolic adverse events}

We believe the authors have significantly underestimated both the frequency and seriousness of the risk of thromboembolic (TE) complications in cardiac surgery patients. They refer to 'the relatively low incidence of thromboembolic events (1-2\%) after the use of rFVIIa' in Levi et al's systematic review of the literature [16], but neglect to inform the reader that over $50 \%$ of the data included in this synthesis came from case reports or series. Furthermore less than $5 \%$ of the patients in this article were surgical patients, the vast majority being haemophiliacs, in which rFVIIa is a licensed treatment for haemorrhage. These are both crucial factors, as they introduce a high risk of both publication and selection bias. Heise et al infer that because TE complications in patients with VAD were not explicitly mentioned in O'Connell et al's paper in 2006 [17] they 'seem to be very rare'. This conclusion simply cannot be drawn from the available data. Whilst the authors refer to this paper a second time, they fail to emphasise that O'Connell et al stressed that most TE adverse events follow the use of rFVIIa for unlabeled indications, and result in serious morbidity and mortality.

It is difficult to know what the real risk of serious TE adverse events in this cohort of patients is. In a systematic data synthesis of the cardiac surgery literature performed early this year, our group reported a TE adverse event rate in adult patients treated for refractory haemorrhage of $5.3 \%$ [18]. This was very similar to the 6\% quoted by Levy et al who reviewed the critical safety data from 13 rFVIIa clinical trials in patients with coagulopathy secondary to anti-coagulation, cirrhosis, or severe traumatic injury [19]. However, we would stress that even these studies are likely to suffer from underreporting. Whatever the rate, the morbidity and mortality of spontaneous arterial or venous thrombosis are severe, and must not be understated.

\section{Conclusion}

It is likely that the level and location of TF expression in patients undergoing VAD surgery is significantly higher and more widespread than in normal subjects, and thus these patients are at risk of spontaneous intra-vascular thrombosis if administered rFVIIa. The level of this risk is currently unquantifiable. We agree wholeheartedly with the authors' conclusion that rFVIIa is a promising therapeutic option when conventional treatments for refractory haemorrhage have been exhausted, and use it in our own clinical practice. However we wish to emphasise that careful risk-benefit analysis must be made before prescribing rFVIIa to any bleeding cardiac patient. Evidence-based recommendations regarding the use of rFVIIa in cardiac surgery are available to the practicing cardiac surgeon or anaesthetist and we refer our colleagues to these guidelines [20-22].

\section{Competing interests}

OW and TA have both received an unrestricted educational grant from NovoNordisk ${ }^{\circledR}$, the manufacturers of Novoseven, to fund their research in this area. The company has had no input into this letter.

\section{Authors' contributions}

OW and TA were equally involved in the conceptualization, research, writing and manuscript preparation of this letter. $\mathrm{AD}$ was responsible for manuscript revision and important intellectual contact. TA is the guarantor. All authors read and approved the final manuscript.

\section{Acknowledgements}

This work was carried out as part of ongoing work into Recombinant Factor VIla being performed within, and funded by, the Department of BioSurgery and Surgical Technology, Imperial College, London. This work has been partly, but not solely, subsidised by an unrestricted educational grant from NovoNordisk ${ }^{\circledR}$, the manufacturers of Novoseven. However, no one except the three named authors were involved in the writing of this manuscript, nor the decision to submit the manuscript for publication.

\section{References}

I. Heise D, Braeuer A, Quintel M: Recombinant activated factor VII (Novo7) in patients with ventricular assist devices: Case report and review of the current literature. Journal of Cardiothoracic Surgery 2007, 2:47.

2. Khan MM, Hattori T, Niewiarowski S, Edmunds LH Jr., Colman RW: Truncated and microparticle-free soluble tissue factor bound to peripheral monocytes preferentially activate factor VII. Thromb Haemost 2006, 95(3):462-468.

3. Diamant M, Nieuwland R, Pablo RF, Sturk A, Smit JW, Radder JK: Elevated numbers of tissue-factor exposing microparticles correlate with components of the metabolic syndrome in uncomplicated type $\mathbf{2}$ diabetes mellitus. Circulation 2002, I 06( I 9):2442-2447.

4. Giesen PL, Rauch U, Bohrmann B, Kling D, Roque M, Fallon JT, Badimon JJ, Himber J, Riederer MA, Nemerson Y: Blood-borne tissue factor: another view of thrombosis. Proc Natl Acad Sci U S A 1999, 96(5):23।|-23।5.

5. Engelmann $B$ : Initiation of coagulation by tissue factor carriers in blood. Blood Cells Mol Dis 2006, 36(2): 188-190.

6. Rauch U, Nemerson $Y$ : Circulating tissue factor and thrombosis. Curr Opin Hematol 2000, 7(5):273-277.

7. Nieuwland R, Berckmans RJ, Rotteveel-Eijkman RC, Maquelin KN, Roozendaal KJ, Jansen PG, ten Have K, Eijsman L, Hack CE, Sturk A: Cell-derived microparticles generated in patients during cardiopulmonary bypass are highly procoagulant. Circulation 1997, 96( I 0):3534-3541.

8. Nijziel M, van Oerle R, van 't Veer C, van Pampus E, Lindhout T, Hamulyak $\mathrm{K}$ : Tissue factor activity in human monocytes is regu- 
lated by plasma: implications for the high and low responder phenomenon. Br J Haematol 200I, I I 2(I):98-I04.

9. Maugeri N, Brambilla M, Camera M, Carbone A, Tremoli E, Donati MB, de Gaetano G, Cerletti C: Human polymorphonuclear leukocytes produce and express functional tissue factor upon stimulation. J Thromb Haemost 2006, 4(6): 1323-1330.

10. Hattori T, Khan MM, Colman RW, Edmunds LH Jr.: Plasma tissue factor plus activated peripheral mononuclear cells activate factors VII and $\mathbf{X}$ in cardiac surgical wounds. J Am Coll Cardiol 2005, 46(4):707-713.

II. Kato $\mathrm{H}$ : Regulation of functions of vascular wall cells by tissue factor pathway inhibitor: basic and clinical aspects. Arterioscler Thromb Vasc Biol 2002, 22(4):539-548.

12. Jude B, Zawadzki C, Susen S, Corseaux D: Relevance of tissue factor in cardiovascular disease. Arch Mal Coeur Vaiss 2005, 98(6):667-67I.

13. Bom VJ, Bertina RM: The contributions of $\mathrm{Ca2+}$, phospholipids and tissue-factor apoprotein to the activation of human blood-coagulation factor $\mathbf{X}$ by activated factor VII. Biochem J 1990, 265(2):327-336.

14. Monroe DM, Hoffman M, Oliver JA, Roberts HR: Platelet activity of high-dose factor $\mathrm{VIla}$ is independent of tissue factor. $\mathrm{Br} J$ Haematol 1997, 99(3):542-547.

15. Hoffman M, Monroe DM, Roberts HR: Human monocytes support factor $\mathbf{X}$ activation by factor $\mathrm{VIla}$, independent of tissue factor: implications for the therapeutic mechanism of highdose factor VIla in hemophilia. Blood 1994, 83(I):38-42.

16. Levi M, Peters M, Buller HR: Efficacy and safety of recombinant factor VIla for treatment of severe bleeding: a systematic review. Crit Care Med 2005, 33(4):883-890.

17. O'Connell KA, Wood J], Wise RP, Lozier JN, Braun MM: Thromboembolic adverse events after use of recombinant human coagulation factor VIla. Jama 2006, 295(3):293-298.

18. Warren O, Mandal K, Hadjianastassiou V, Knowlton L, Panesar S, John K, Darzi A, Athanasiou T: Recombinant activated factor VII in cardiac surgery: a systematic review. Ann Thorac Surg 2007, 83(2):707-7|4.

19. Levy JH, Fingerhut A, Brott T, Langbakke IH, Erhardtsen E, Porte RJ: Recombinant factor VIla in patients with coagulopathy secondary to anticoagulant therapy, cirrhosis, or severe traumatic injury: review of safety profile. Transfusion 2006, 46(6):919-933.

20. Ferraris VA, Ferraris SP, Saha SP, Hessel EA 2nd, Haan CK, Royston BD, Bridges CR, Higgins RS, Despotis G, Brown JR, Spiess BD, ShoreLesserson L, Stafford-Smith M, Mazer CD, Bennett-Guerrero E, Hill SE, Body S: Perioperative blood transfusion and blood conservation in cardiac surgery: the Society of Thoracic Surgeons and The Society of Cardiovascular Anesthesiologists clinical practice guideline. Ann Thorac Surg 2007, 83(5 Suppl):S27-86.

21. Shander A, Goodnough LT, Ratko T, A. MK, Cohn S, Diringer M, Edmunds H, Lawson J, MacLaren R, Ness P, Shere-Wolfe R, Dubois $R$ : Consensus recommendations for the off-label use of recombinant human factor VIla (NovoSeven) therapy. Pharmacy \& Therapeutics 2005, 30:644-658.

22. Roberts HR, Monroe DM, White GC: The use of recombinant factor VIla in the treatment of bleeding disorders. Blood 2004, I04(I3):3858-3864.

\section{Publish with Biomed Central and every} scientist can read your work free of charge

"BioMed Central will be the most significant development for disseminating the results of biomedical research in our lifetime. "

Sir Paul Nurse, Cancer Research UK

Your research papers will be:

- available free of charge to the entire biomedical community

- peer reviewed and published immediately upon acceptance

- cited in PubMed and archived on PubMed Central

- yours - you keep the copyright 